\title{
Medicolegal Importance of the Foramen Ovale, in Determination of Sex, in Dried Adult Egyptians Human Skulls (Morphometric \& Morphological Study)
}

\author{
Ayman A. Nagy ${ }^{1}$, Nasr A.Y. ${ }^{2}$, Abdel Moty Kabbash ${ }^{1}$
}

\begin{abstract}
KEYWORDS

Identification,

Foramen ovale morphology

and morphometery,

Gender identification.

Anatomical variations of the skull foramens have been of interest for anthropologists, forensic scientists and neuroanatomists. This study aimed to determine the effectiveness of the morphometric measurements foramen ovale to proof its anatomical variations for sex determination in Egyptian dried adult skulls. This study included 25 dry adult human skulls (50 FO); 13 males and 12 females. A digital caliper was used to measure the dimensions of the FO (Length and width); these measurements were taken by two researchers separately. All measurements were conducted bilaterally and repeated three times, the data were statistically analyzed and a comparison between both sides (right and left) FO in skulls of both sexes were done. It was found that there wane differences between the averages meas \pm SD length and the width of both sides of FO (left and right) in male skulls with no statistical significance. The same results were found in female skulls. Based on the gender, the linear metric measurements of F.O in skulls of both sexes showed statistical significant difference on the average means \pm SD in the length and width of the right and left sides. Various shapes of the F.O were observed in the studied skulls, and the most common shape was the oval shape followed by the almond shape. It can be concluded that, the metric analysis of FO can be useful as a supplement to other skeletal measurements aiming at establishing gender identity of individuals. Also the foramen ovale has a great variation in different countries.
\end{abstract}

\section{Introduction}

The anatomical variations of foramens of the skull have been of interest for anthropologists, forensic scientists and neuroanatomists (Humphrey et al., 1999). These variants between different populations may be referred to socioeconomic factors,

\footnotetext{
${ }^{(1)}$ Forensic Medicine and Clinical Toxicology Department, Tanta University, Egypt.

(2) Anatomy Department, Faculty of Medicine, Zagazig University, Zagazig, Egypt and King Abdul-Aziz University, Jeddah, Kingdom of Saudi Arabia.
}

environmental, as well as genetic factors (Saunders and Yang, 1999).

Craniometrical measurements of different anatomical features of skulls enable us to determine the sex as a part of complete identification of body, which is an important component both in criminal investigations and in general preparedness for mass fatality incidents (Rosing, 2007).

The differences in measurements and shapes of foramina of skulls in different genders are mainly determined by genetic factors as well as nutrition, hormones, or muscles (Gunay, 2000). The bones of skull 
base are protected by its anatomical position and surrounding soft tissues, which makes it useful for identification in a case of destruction of cranial and facial bones as in case of mass disasters, explosion, or violence, that make it difficult for identification or sex determination (Graw, 2001).

Foraminen ovale (FO) are one of the important foramina of the middle cranial fossa. (Sharma et al, 2016). It lies close to the posterior border of the pterygoid plate, posterior to the foramen rotundum. The lesser petrosal nerve, mandibular nerve and the accessory meningeal artery, are its main components (Standring, 2006).

Normally, the FO has a different linear measurements and shapes. Very limited studies had been done to determine those variants in different populations.

This study aimed to determine the effectiveness of the morphometric measurements of FO to proof its anatomical variations for sex determination in Egyptian dried adult skulls.

\section{Material and Methods}

The material for the present study included twenty five dry adult human skulls (50 FO); 13 males and 12 females skulls. The skulls were obtained from the Department of Anatomy, Faculty of Medicine, University of Tanta, Egypt. The approval of this study was obtained from the Ethics committee, Quality assurance Unit of Faculty of Medicine, University of Tanta, Egypt. A digital caliper (JOMARCA) of $0.1 \mathrm{~mm}$ was used to measure the dimensions of the FO (length and width), these measurements were taken three times by two researchers separately, the averages mean \pm SD of each researcher was calculated then the averages mean $\pm \mathrm{SD}$ of both results was recorded. All measurements were conducted bilaterally. Broken or fragmented skulls especially at the pterygoid plate were excluded and data were recorded and a comparison between both foramina (Right and left) in both sexes of skulls (Male and female skulls were determined according to the anatomical features.

\section{Statistical Analysis}

Statistical analysis of the present study was conducted using the software of SPSS Inc. Chicago, IL, USA, version 21.Quantitative data was tabulated in mean \pm SD for parametric variables. Chi square test was used to examine the association between categorical variables. For parametric variables, Student t test was used to compare the mean between two independent groups. The level of significance was adopted at the $5 \%$ and the significance threshold ( $p$ value) was set at less than 0.05 .

\section{Results}

\section{Morphometric results:}

It was found that the mean $\pm \mathrm{SD}$ of the length of FO on the left side in males skull was $7.7 \pm 1.21 \mathrm{~mm}$ while on the right side it was $6.9 \pm 1.13 \mathrm{~mm}$ with no statistical significant difference $\mathrm{p} 1>0.05$ (Table1). The average mean \pm SD of the width of the foramen ovale in male skull was $5.63 \pm 1.26 \mathrm{~mm}$ and $5.58 \pm$ $1.18 \mathrm{~mm}$ for left and right sides respectively, these results were of no significant variance (p1>0.05) (Table2).

Regarding female skulls the average mean \pm SD of the length of F.O was $6.9 \pm 1.13$ $\mathrm{mm}$ and $7.02 \pm 1.19 \mathrm{~mm}$ on the left and right sides respectively. The average mean $\pm \mathrm{SD}$ of the width of F.O of the females skulls were 5.1 
$\pm 0.97 \mathrm{~mm}$ and $5.02 \pm 1.08 \mathrm{~mm}$ in the left and right sides respectively. There was no significant variance between the length of both sides as well as the width of both sides in the female skulls $(\mathrm{p} 1>0.05)$ (Tables $1 \& 2)$.

Based on the gender, the linear metric measurements of F.O in male and female skulls showed statistical significant difference of the average means \pm SD in the length and width. As the length of the left side was $7.7 \pm 1.21$ $\mathrm{mm}$ and $6.9 \pm 1.13 \mathrm{~mm}$ in males and females respectively $(\mathrm{p}<0.05)$ while on the right side it was $7.68 \pm 1.32 \mathrm{~mm}$ and $7.02 \pm 1.19 \mathrm{~mm}$ in males and females respectively $(\mathrm{p}<0.05)$ as shown in (Table 1).

While the averages mean \pm SD of width of the foramen oval on left side, it was $5.63 \pm$ $1.26 \mathrm{~mm}$ and $5.1 \pm 0.97 \mathrm{~mm}$ in males and females respectively $(p>0.05)$ as shown in
(Table 2). The results showed statistical significance $(p<0.05)$ between the averages mean \pm SD of the width on the right side $5.58 \pm$ $1.18 \mathrm{~mm}$ and $5.02 \pm 1.08 \mathrm{~mm}$ of males and females respectively.

\section{Morphological Study}

Various shapes of the F.O were observed in studied skulls. The results showed typical foramina oval (Fig.1a \& b) in 58\% (30 on the, right side, 28 on the left), almond shape in $33 \%$ (Fig.2) (16 and 17 right and left foramina respectively), other forms such as slit like and bizarre shapes (Fig.3, 4) 9\% (4 right, 5 left) and there was no statistical difference between different shapes on both sides ( $p>0.05)$ (Table 3).

Table (1): The length of the left and right foramen ovale, in both male and female skulls.

\begin{tabular}{|l|c|c|c|c|}
\hline $\begin{array}{c}\text { Length in mm } \\
(\text { Mean } \pm \text { SD) }\end{array}$ & $\begin{array}{c}\text { Males } \\
(\mathbf{n}=\mathbf{1 3})\end{array}$ & $\begin{array}{c}\text { Females } \\
(\mathbf{n}=\mathbf{1 2})\end{array}$ & t. test & p. value \\
\hline Left FO & $7.7 \pm 1.21$ & $6.9 \pm 1.13$ & 3.423 & $0.001^{*}$ \\
\hline Right FO & $7.68 \pm 1.32$ & $7.02 \pm 1.19$ & 2.632 & $0.001^{*}$ \\
\hline t. test & 0.082 & 0.523 & & \\
\hline p1. value & 0.937 & 0.606 & & \\
\hline
\end{tabular}

SD: standard deviation, mm: millimeter, n: number, F.O: foramen ovale, t: Independent samples test, *means significant, $\mathrm{p}=$ difference between males $\&$ females and $\mathrm{p} 1=$ difference between left and right FO. 
Table (2): The width of the left and right foramen ovale, in both male and female skulls.

\begin{tabular}{|l|c|c|c|c|}
\hline \multicolumn{1}{|c|}{$\begin{array}{c}\text { Width in mm } \\
(\text { Mean } \pm \text { SD) }\end{array}$} & $\begin{array}{c}\text { Males } \\
(\mathbf{n}=\mathbf{1 3})\end{array}$ & $\begin{array}{c}\text { Females } \\
(\mathbf{n = 1 2})\end{array}$ & t. test & p value \\
\hline Left & $5.63 \pm 1.26$ & $5.1 \pm 0.97$ & 2.362 & $0.020^{*}$ \\
\hline Right & $5.58 \pm 1.18$ & $5.02 \pm 1.08$ & 2.483 & $0.015^{*}$ \\
\hline t. test & 0.203 & 0.394 & & \\
\hline p1. value & 0.838 & 0.698 & & \\
\hline
\end{tabular}

SD: standard deviation, mm: millimeter, n: number, F.O: foramen ovale, t: Independent samples test, *means significant, $\mathrm{p}=$ difference between males $\&$ females and $\mathrm{p} 1=$ difference between left and right FO.

Table (3): Morphology of the foramen ovale on the right and left sides of the studied skulls.

\begin{tabular}{|l|c|c|c|c|c|c|}
\hline \multirow{2}{*}{} & \multicolumn{2}{|c|}{ Rt side } & \multicolumn{2}{c|}{ Lt side } & \multicolumn{2}{c|}{ Total } \\
\cline { 2 - 8 } & $\mathbf{n}$ & $\mathbf{\%}$ & $\mathbf{n}$ & $\mathbf{\%}$ & $\mathbf{n}$ & $\%$ \\
\hline \multirow{2}{*}{ Oval shape } & 30 & 60 & 28 & 56 & 58 & 58 \\
\hline Almond shape & 16 & 32 & 17 & 34 & 33 & 33 \\
\hline Other forms & 4 & 8 & 5 & 10 & 9 & 9 \\
\hline Total & 50 & 100 & 50 & 100 & 100 & 100 \\
\hline \multirow{2}{*}{ Chi-square } & $\chi^{\mathbf{2}}$ & \multicolumn{7}{|c|}{0.213} \\
\cline { 2 - 8 } & $\mathbf{p}$ p-value & \multicolumn{7}{|c|}{0.901} \\
\hline
\end{tabular}

Rt: Right side; Lt: left side; n: number; \%: percentage; $\chi^{2}$ : Pearson's Chi Square test.

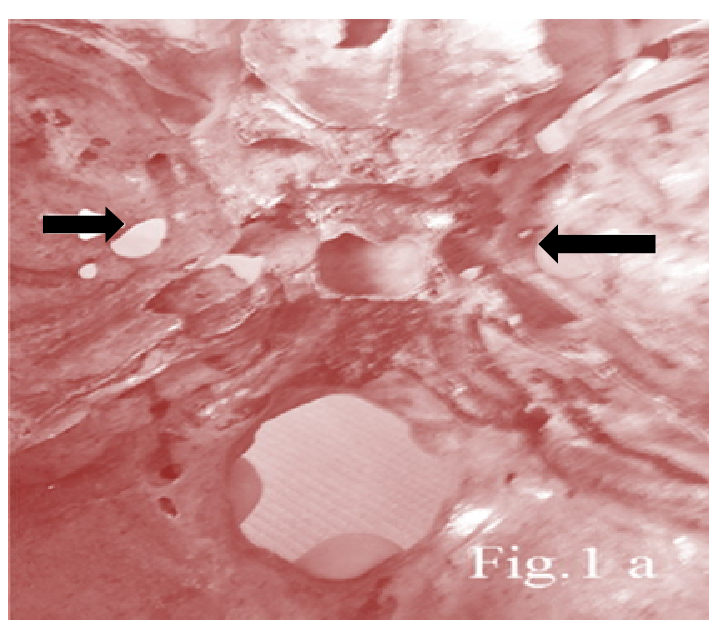

Fig. (1 a): Showing oval shape of foramen ovale bilaterally (arrow).

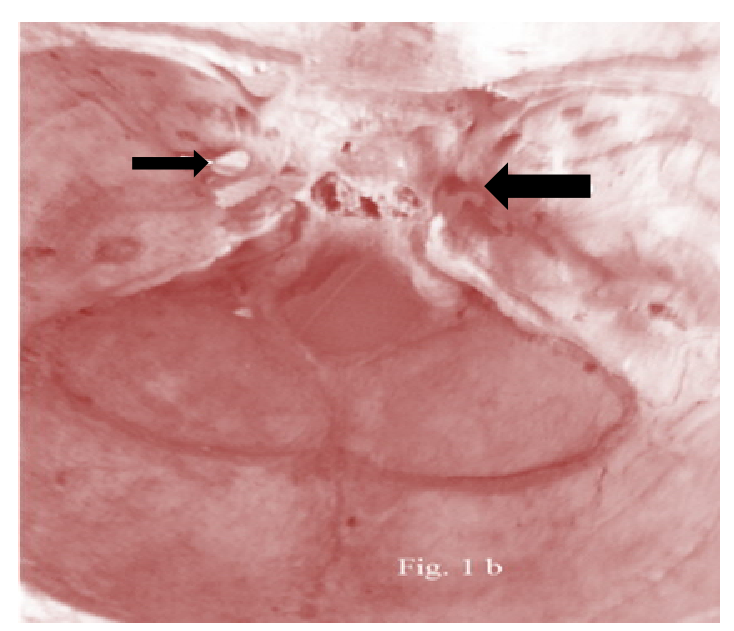

Fig. (1 b): Showing oval shape of foramen ovale bilaterally (arrow). 

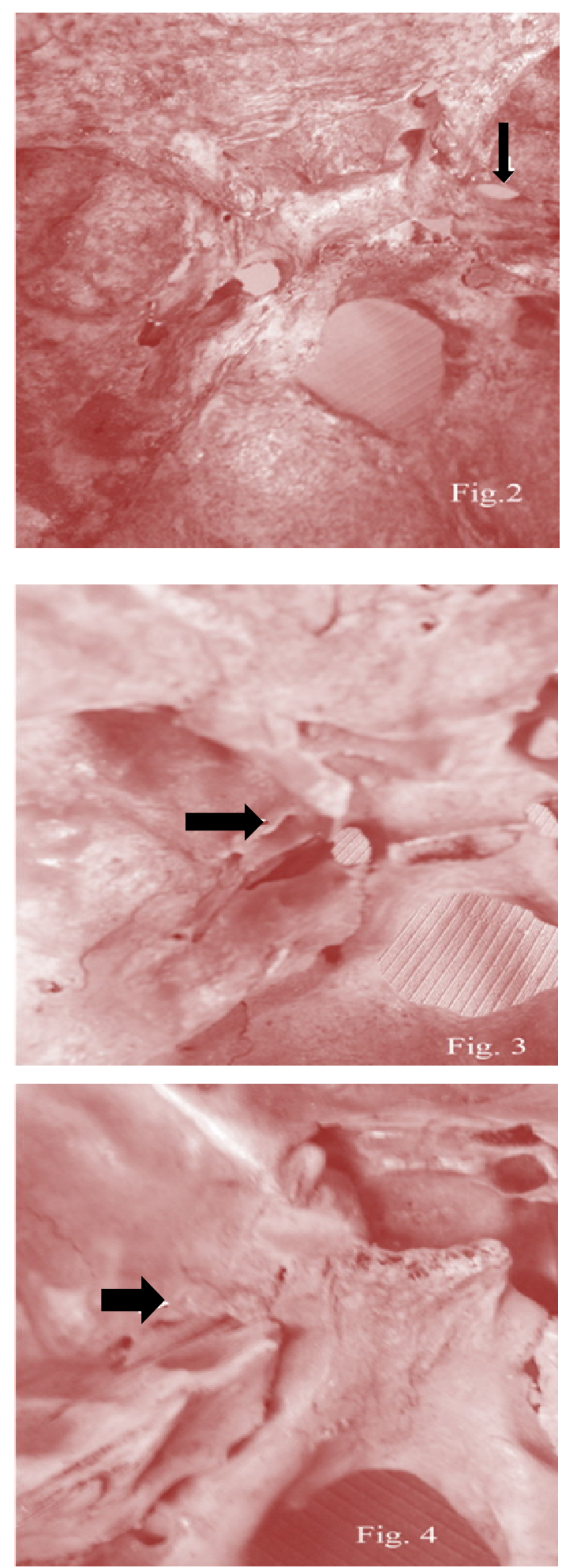

Fig. (2): A photograph showing almond shape of foramen ovale on the right side (arrow).

Fig. (3): A photograph showing slit like shape of foramen ovale on left side (arrow).

Fig. (4): A photograph showing bizarre shape like (due to projection of spine) of foramen ovale on left side (arrow). 


\section{Discussion}

The FO can be seen as an oval ring in the sphenoid bone in its greater wings, during the $7^{\text {th }}$ month of the intrauterine life. The sphenoid bone has developed from endochondral and intramembranous ossification centers which give the lesser and great wings as well as body of the sphenoid bone. Anatomically FO lies close to the upper border of lateral pterygoid body, between the foramen rotundum and foramen spinosum (Standring, 2006). A large number of studies have been done worldwide on the morphometric measurements of FO giving insight into association between its morphology and its neurovascular anatomy (Jyothsna et al., 2013).

In this study, it was found that the average mean of antero-posterior measure of FO on the right and left side in both males and females were different. This difference between both sides of FO in males and females was found to be statistically insignificant. Regarding the width of FO in this study, the average meas of width of FO of the right and left side in both males and females were different. This was insignificant in both sexes. Even though the left side was longer than the right side in both sexes. Similarly in previous studies on different populations, carried out on Nepal populations, there was insignificant difference between the metric length and width of both sides, as reported by Biswabina et al. (2005). As the mean length was $7.46 \pm 1.41 \mathrm{~mm}, 7.01 \pm 1.41$ $\mathrm{mm}$ and the mean width was $3.21 \pm 0.02 \mathrm{~mm}$, $3.29 \pm 0.58 \mathrm{~mm}$ on the right and left side respectively. Another study was carried out on Indian populations by Someshet al. (2011) showing that the mean length was $7.64 \pm 1.19$ $\mathrm{mm}, 7.561 \pm 1.123 \mathrm{~mm}$ while the mean width of the FO of the right and left side respectively was $5.128 \pm 0.827 \mathrm{~mm}$, and $5.244 \pm 0.950$ which were of no significant difference. In Japanese population a comparison of the length of FO in adults, fetus and juvenile skulls, in a study by Yanagi (1987) showed that the average maximal length of FO was 7.48 in adults. Studying the postnatal enlargement of foramen ovale in living German populations it was reported that the average length of FO was $7.2 \mathrm{~mm}$ while the width was $3.7 \mathrm{~mm}$ as reported by Lang et al. (1984). This difference in dimensions was giving evidence that the skulls are bilaterally asymmetrical.

In the present study, it was found that there is a statistical significant difference in metric measurement of the FO in dried human adult skulls between males and females in the measurements of the dimensions of the right and left sides respectively. In a study done by Burdan et al. (2011) on skulls in adults from the Lublin region (Poland), comparative metric measurements of FO in males and females through examination by computed tomography, they reported insignificant higher length and width measurement of FO in males than females. This difference in results may be attributed to different methods of measurement and different type of skulls (dry and living skulls and bilaterally asymmetrical skull development).

Analyzing the variation in the shape of the FO, it was found that the oval shape is the common shape as it represents $60 \%$ of the right side and $56 \%$ of the left side foramina, while the almond shape was the second variant as it represents $32 \%$ and $34 \%$ of the right and left foramina respectively. Other forms represent 4$5 \%$. This comes in accordance with previous studies done by Yanagi (1987) and Somesh et 
al. (2011), as the oval shape was the common, then the almond shape.

The exact cause of the observed variation in different studies is difficult to be determined. It could be related to genetic, racial, developmental, nutritional or other unknown factors (Sigh and Pathak, 2013).

\section{Conclusions}

There is a statistical insignificant difference in linear metric measurements of FO on both sides. The left side of the FO is longer and wider than the right side. There is a statistical significant difference in linear metric measurement (length and width of the FO) on both sides between males and females adult dried skulls. However, from forensic point of view, the metric analysis of FO could be useful as a supplement to other skeletal measurements aiming to establishing the gender of individuals. The foramen ovale has a great variation in different countries. The knowledge of morphometric analysis in different population is necessary for forensic anthropologist and clinicians as neurosurgeons.

\section{References}

Biswabina, R.; Nitrupma, G. and Supriya, G. (2005): "Anatomic variations of the foramen ovale". Kathmandu University Medical Journal, 3(1): 6468.

Burdan, F.I.; Umlawska, W.; Dwrzanski, W.; et al. (2011): "Anatomical variances and dimensions of the superior orbital fissure and foramen ovale in adults". Folia Morphol.,70 (4): 263-271.

Graw, M. (2001): Morphometrische und morphognostische Geschlechtsdiagnostik van der menschlichen Schädelbasis. In: Osteologische Identifikation und Altersschätzung. Oehmichen, $\mathrm{M}$ and Geserick, G. (Eds.). Lübeck: SchmidtRömhild, P.P.103-121.

Gunay, Y. and Altinkok, M. (2000): "The value of the size of foramen magnum in sex determination". Journal of Clinical Forensic Medicine, 7: 147-149.

Humphrey, L.T.; Dean, M.C. and Striger, C.B. (1999): "Morphological variation in great ape and modern human mandibles". Journal of Anatomy, 195(4): 491-513.

Jyothsna, P.; Kumar, N. and Mohandas Rao, K.G. (2013): "The foramen ovale morphometry of sphenoid bone in South India". J. Clin. Diagn. Res., 7 (12): 26682670 .

Lang, J.; Maier, R. and Schafhauser, O. (1984): "Postnatal enlargement of the foramina rotundum, ovale et spinosum and their topographical changes". Anatomischer Anzeiger, 156 (5): 351387.

Rosing, F.W.; Graw, M., Marre, B.; et al. (2007): "Recommendations for the forensic diagnosis of sex and age from skeletons". Homo. J. Comp. Biology, 58: 75-89.

Saunders, S.R. and Yang, D. (1999): Sex determination: $\mathrm{XX}$ or $\mathrm{XY}$ from the human skeleton. In: Forensic Osteological Analysis. Fairgrieve, SI. (Ed.). Springfield: Charles C. Thomas, P.P. 36-59. 
Sharma, S.; Thakur, C. and Shankar, B. (2016): "Study of anatomic variant of foramen ovale and spinosum in dried human skulls". Int. J. Anat. Res., 4(1) : 2002-2006.

Sigh, J. and Pathak, R.K. (2013): "Sex and age related non-metric variation of the human sternum in a Northwest Indian postmortem sample: A pilot study". Forensic Sci. Int., 228 (1-3):1181e1$181 \mathrm{e} 12$.

Somesh, M.S.; Sridevi, H.B.; Prabhu, L.V.; et al. (2011): "A morphometric study of foramen ovale". Journal Turkish Neurosurgery, 21(3): 378-383.

Standring, S. (2006): The anatomical basis of clinical practice in external skull. In: Anatomy Gray's, 39 ${ }^{\text {th }}$ Ed. London: Churchill living stone Elsevier Limited, P.P.460 -462.

Yanagi, S. (1987): "Developmental studies on the foramen rotundum, foramen ovale and foramen spinosum of the human sphenoid bone". The Hokkaido Journal of Medical Science, 62 (3): 485 - 496. 


\section{الأهمية الطبية الشرعية لثقب البيضة في تحديد الجنس في الجماجم الجافة للمصريين \\ البالغين (دراسة قياسية وشكلية)}

\section{أيمن عبد الحميد ناجي ، أشرف يوسف نصر ، عبد المعطي كباش'}

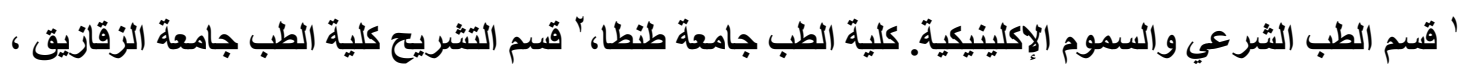
جمهورية مصر العربية وكلية الطب جامعة الملك عبد العزيز جدة المملكة العربية السعودية.

تعتبر الاختلافات التشريحية لثقوب الجمجمـة ذات أهميـة لعلمـاء الأنثروبولوجيا، و علمـاء الطب الشرعي

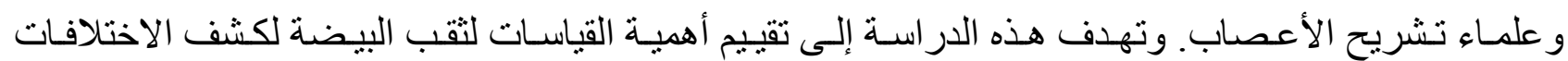
التشريحية والخصائص الثكلية بالنسبة لتحديد الجنس في جماجم المصريين البالغين.استخدم في هذا البحث عدد

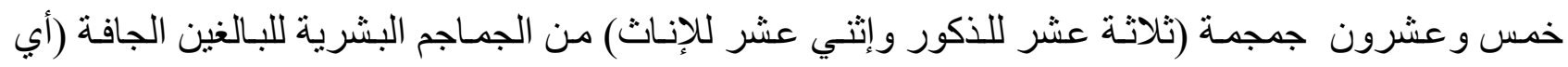

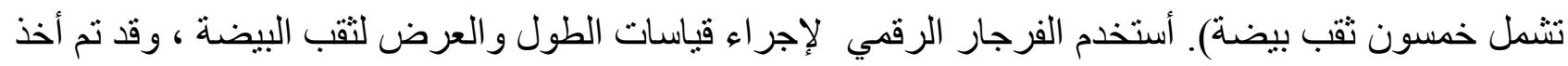

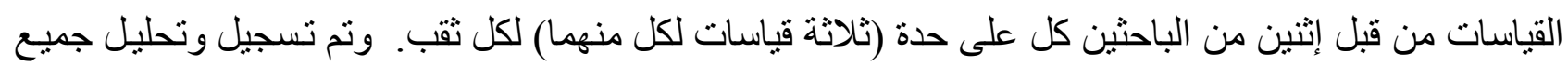
القياسـات إحصائيا و المقارنـة بين كـلا الثقبين (التقب الأيمـن و الأيسر ) في كل مـن جمـاجم الذكور و الإنـاث . ثبت من البحث وجود إختلافات غير ذات قيمة إعتباريسة في قياس عرض وطول ثقب البيضة الأيسر والأيمن في جماجم الذكور. وقد وجدت النتائج نفسها في جماجم الإناث وبالنسبة للجنس، فقد تبين وجود إختلافات ذات قيمة إعتبارية في قياس إنساع وطول ثقب البيضة الأيسر والأيمن بين مجمو عة الذكور والإناث.

و عند در اسـة شكل ثقب البيضة فحى نفس الجمـاجم محل الدر اسـة تبين أن الشكل البيضـاوي هو الشكل

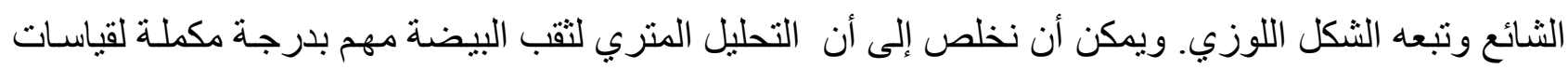

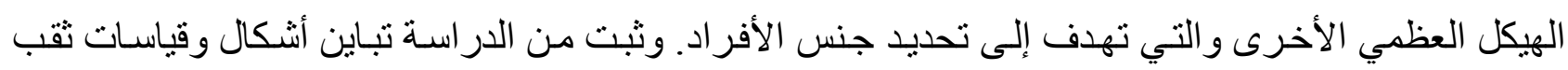
البيضة في مختلف البلدان. 